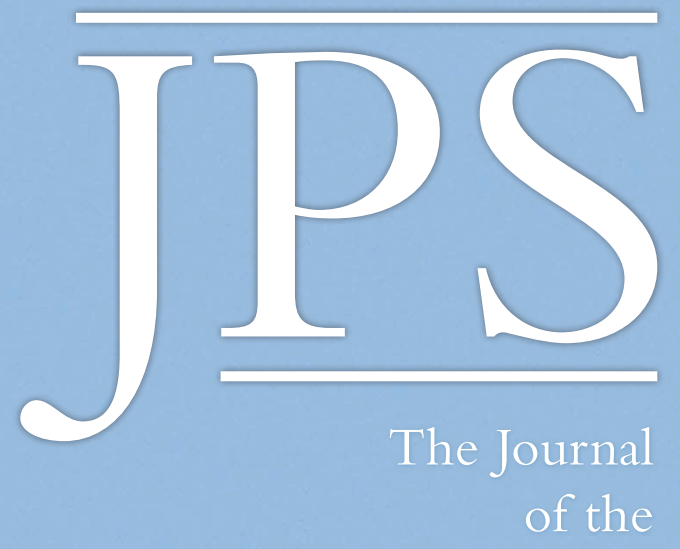

Polynesian Society

VOLUME 126 No.3 SEPTEMBER 2017

THE POLYNESIAN SOCIETY THE UNIVERSITY OF AUCKLAND NEW ZEALAND
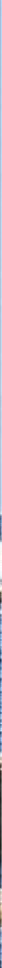


\title{
NEW AMS RADIOCARBON DATES AND A RE-EVALUATION OF THE CULTURAL SEQUENCE OF TIKOPIA ISLAND, SOUTHEAST SOLOMON ISLANDS
}

\author{
PATRICK V. KIRCH \\ University of California \\ JILLIAN A. SWIFT \\ Max Planck Institute for the Science of Human History
}

The small volcanic island of Tikopia, situated at a geographically key intersection between the southeastern terminus of the Solomon Islands and the northern end of the Vanuatu archipelago, first gained anthropological fame through the extensive ethnographic field research and writings of Sir Raymond Firth $(1936,1939)$. Tikopia is a Polynesian Outlier, one of about 18 such islands lying within Melanesia and Micronesia whose populations speak Polynesian languages (Feinberg and Scaglion 2012). Based on Tikopia oral traditions, Firth (1961) opined that many of the Tikopia lineages traced their origins to islands in Western Polynesia, with ancestors arriving from Tonga, Sāmoa, Futuna, 'Uvea or Rotuma.

In 1977-78, as part of the second phase of the Southeast Solomon Islands Culture History Program organised by the Bernice P. Bishop Museum and funded by the U.S. National Science Foundation, the senior author and Douglas E. Yen carried out two seasons of archaeological and ethnobotanical investigations on Tikopia (Kirch and Yen 1982). Excavations totalling more than $271 \mathrm{~m}^{3}$ at 26 different localities around the island revealed well-stratified archaeological deposits, yielding large assemblages of artefacts $(5,650$ objects) and faunal remains ( $>35,000$ NISP vertebrate remains; 1.03 metric tons of mollusc remains). The cultural sequence of Tikopia proved to be complex, with three discrete prehistoric cultural phases recognised on the basis of changes in the material cultural assemblages. The initial Kiki Phase, estimated to have commenced c. $900 \mathrm{BC}$, was marked by the presence of sandtempered pottery related to the early Lapita Cultural Complex (Green 1979). This was followed by the Sinapupu Phase during which incised Mangaasistyle ceramics (Garanger 1971, 1972) were imported into Tikopia from one or more localities in the Vanuatu archipelago. The final Tuakamali Phase lacked ceramics altogether but contained distinctly Polynesian-style adzes and fishing gear indicative of the arrival of voyagers from Western Polynesia (as the oral traditions suggested). It was therefore during the Tuakamali Phase that Tikopia took on its cultural and linguistic characteristics as a Polynesian 
Outlier. The Tikopia cultural sequence, as defined by Kirch and Yen (1982: 311-34; see also Kirch 1984, 1986, 1997) remains one of the best-defined archaeological sequences for any Polynesian Outlier, and is of considerable importance for our understanding of the prehistory of the southwestern Pacific.

Kirch and Yen (1982: 311-17, Table 50) submitted 20 samples from their Tikopia excavations, primarily of wood charcoal or carbonised coconut shell, to the radiocarbon laboratories of Teledyne Isotopes, University of California at Riverside, Beta Analytic, and the Australian National University. Based on the ${ }^{14} \mathrm{C}$ results received from these laboratories, the three-phase Tikopia cultural sequence was pegged to a chronological sequence as follows: Kiki Phase, 900-100 BC; Sinapupu Phase, 100 BC-AD 1200; and Tuakamali Phase, AD 1200-1800.

From the perspective of the many advances that have been made in sample selection, preparation and ${ }^{14} \mathrm{C}$ dating methods, more than three decades after these initial radiocarbon dates were run, it is apparent that the initial programme of dating the Tikopia sequence suffered from several shortcomings. First, although it was recognised that some samples contained carbonised coconut (Cocos nucifera) shell (endocarp), the wood charcoal samples were not botanically identified, leaving open the possibility that some samples could have included charcoal from old-growth trees or even driftwood, a problem that later became apparent in the dating of archaeological sites in Eastern Polynesia (Spriggs and Anderson 1993). Second, $\delta^{13} \mathrm{C}$ values were not determined for the dated samples and the reported ages were based on an assumed $\delta^{13} \mathrm{C}$ value of $-25.0 \%$. For most samples this assumption was probably reasonably accurate, although for one sample of human bone and another of Thalassia, a genus of seagrass with $\mathrm{C}_{4}$-like carbon stable isotope ratios, this is more questionable. In addition, radiocarbon laboratories at the beginning of the 1980s were still using the liquid scintillation method of beta-particle decay counting, with standard errors $(1 \sigma)$ for the Tikopia samples ranging from $\pm 75 \mathrm{yr}$ at best, and up to $\pm 165 \mathrm{yr}$ in the case of two samples. Finally, the calibration of radiocarbon samples using calibration curves derived from dendrochronologically dated bristlecone pines was then in its infancy. Kirch and Yen (1982: 312, Table 50) used the early calibration tables of Michael and Ralph (1972) and of Damon et al. (1972) to derive "corrected dates" for the Tikopia samples. Table 1 lists the original 20 radiocarbon dates, given here with new calibrated age ranges, calibrated using OxCal v4.2.4 with the SHCal13 atmospheric calibration curve (Bronk Ramsey 2009a; Hogg et al. 2013).

Given these issues, as well as the continued importance of the Tikopia cultural sequence for our understanding of southwestern Pacific prehistory, additional re-dating of archaeological samples from Tikopia seemed desirable. The opportunity to carry out such a re-dating program arose in 2015 in conjunction with Swift's dissertation research on bone collagen stable isotope 
analysis of Pacific rat (Rattus exulans) remains recovered from several Pacific archaeological assemblages, including Tikopia. Drawing upon the Kirch and Yen 1977-78 collections that have been curated in the Bishop Museum, samples of rat bone, pig (Sus scrofa) teeth, and previously undated charcoal samples were selected for AMS radiocarbon dating. In this paper we present the results of 13 new AMS dates, along with a Bayesian calibration model that combines the new AMS dates with the previously dated samples in order to reassess the Tikopia cultural chronology.

\section{MATERIALS AND METHODS}

Rat and pig elements were subsampled for stable isotope analysis prior to submission for AMS radiocarbon dating; specifically bone collagen and tooth dentin were analysed for carbon and nitrogen, and tooth enamel for carbon and oxygen. Rat bone elements were sonicated in ultrapure water for four hours, dried and abraded to remove surface contaminants. Samples were then crushed into chunks $(\sim 1 \mathrm{~mm})$ with the aid of an agate mortar and pestle. Approximately half of each sample was reserved for future stable isotope analysis by Swift. Pig teeth were sampled for enamel and dentin just above the cemento-enamel junction using a Foredom SR-series motor and diamond-tipped drill bit, and the remainder of each tooth was submitted for AMS dating.

Curated charcoal samples from several stratigraphic contexts excavated in 1977-78 were examined in the laboratory by PVK, and carbonised fragments of coconut (Cocos nucifera) endocarp were extracted whenever these were present. Coconut endocarp (the hard "shell" of the nut) burns with a hot fire and is a preferred fuel for igniting earth ovens on Tikopia and elsewhere in Polynesia. The carbonised endocarp, with its two parallel surfaces and hard, shiny texture, is readily identifiable.

All samples for radiocarbon dating were submitted to the W.M. Keck Carbon Cycle Accelerator Mass Spectrometry Laboratory at the University of California, Irvine. When sample sizes permitted, submitted bone and tooth dentin collagen samples were also analysed separately for $\delta^{13} \mathrm{C}$ and $\delta^{15} \mathrm{~N}$. The samples were radiocarbon dated using a $500 \mathrm{kV}$ compact AMS unit from the National Electrostatics Corporation (Southon et al. 2004). $\delta^{13} \mathrm{C}$ values were measured to a precision of $<0.1 \%$ relative to standards traceable to Pee Dee Belemnite (PDB), using a Thermo Finnigan Delta Plus stable isotope ratio mass spectrometer (IRMS) with gas bench input. Aliquots of ultra filtered bone and tooth dentin collagen were analysed for $\delta^{13} \mathrm{C}$ and $\delta^{15} \mathrm{~N}$ to a precision of $<0.1 \%$ and $<0.2 \%$, respectively, using a Fisons NA $1500 \mathrm{NC}$ elemental analyser/Finnigan Delta Plus IRMS (J. Southon, pers. comm., 2015). All results have been corrected for isotopic fractionation according to the conventions of Stuiver and Polach (1977), with $\delta^{13} \mathrm{C}$ values measured on prepared graphite using the AMS spectrometer. 


\begin{tabular}{|c|c|c|c|c|c|c|c|c|c|c|}
\hline 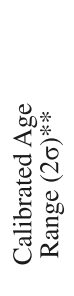 & 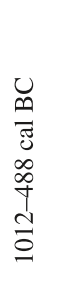 & 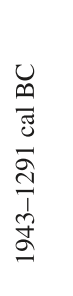 & 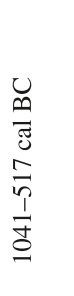 & 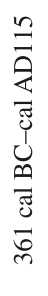 & 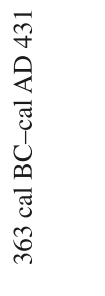 & 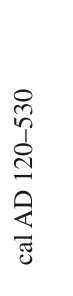 & 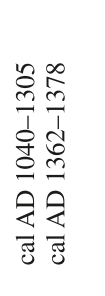 & 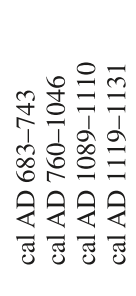 & 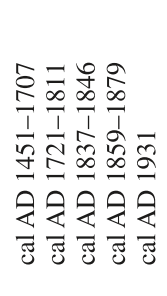 & 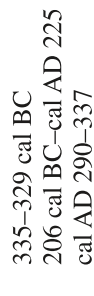 \\
\hline 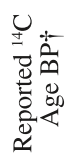 & $\begin{array}{l}8 \\
a+1 \\
+1 \\
\& \\
0 \\
0\end{array}$ & $\begin{array}{l}\stackrel{0}{n} \\
+1 \\
+1 \\
0 \\
m \\
m\end{array}$ & $\begin{array}{l}8 \\
+1 \\
+1 \\
o \\
o \\
i\end{array}$ & 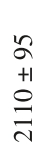 & $\begin{array}{l}n \\
2 \\
+1 \\
n \\
2 \\
2\end{array}$ & $\begin{array}{l}n \\
\infty \\
+1 \\
8 \\
0 \\
-1\end{array}$ & $\begin{array}{l}n \\
+1 \\
\infty \\
\infty \\
\infty\end{array}$ & $\begin{array}{l}n \\
\infty \\
+1 \\
n \\
0 \\
=\end{array}$ & $\begin{array}{l}n \\
+1 \\
0 \\
0\end{array}$ & $\begin{array}{l}8 \\
+1 \\
8 \\
8\end{array}$ \\
\hline $\begin{array}{l}\frac{. \pi}{\bar{J}} \\
\frac{\pi}{\Sigma} \\
\Sigma\end{array}$ & $\begin{array}{l}\overline{0} \\
\text { ర్ } \\
\text { త్ర }\end{array}$ & 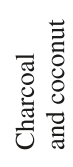 & 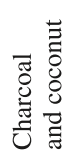 & 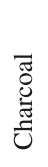 & $\begin{array}{l}\overline{0} \\
\text { : } \\
\text { లే }\end{array}$ & $\begin{array}{l}\widetilde{0} \\
0 \\
\bar{J} \\
\bar{U}\end{array}$ & 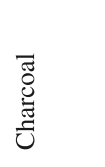 & 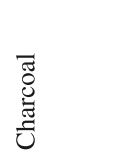 & $\begin{array}{l}\stackrel{0}{0} \\
\text { : } \\
\text { : } \\
\text { 胥 }\end{array}$ & 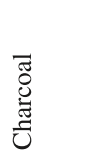 \\
\hline 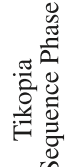 & 音 & $\begin{array}{l}\sqrt{3} \\
\frac{1}{2} \\
0\end{array}$ & $\vec{a}$ & 音 & 㟒芯 & 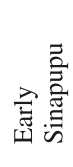 & 忐 & 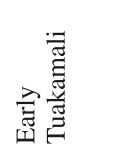 & 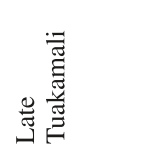 & 空芯 \\
\hline 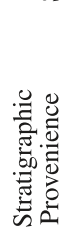 & 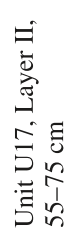 & 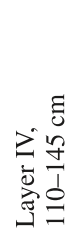 & 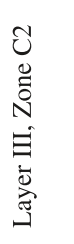 & 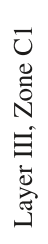 & 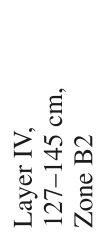 & 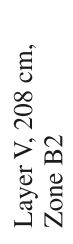 & 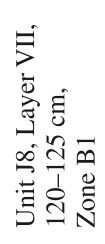 & 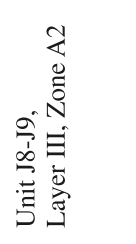 & 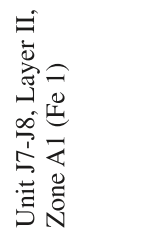 & 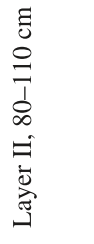 \\
\hline 的离 & $\underset{⿱ ⺌}{\stackrel{\forall}{*}}$ & $\begin{array}{l}\tilde{n} \\
\stackrel{1}{n}\end{array}$ & 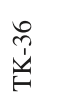 & $\begin{array}{l}\stackrel{\infty}{1} \\
\stackrel{1}{\mid c}\end{array}$ & 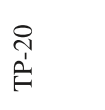 & $\begin{array}{l}\stackrel{\overbrace{}}{1} \\
\stackrel{1}{1}\end{array}$ & $\overrightarrow{\check{y}}$ & 光 & $\vec{y}$ & $\stackrel{N}{\stackrel{1}{\prime \prime}}$ \\
\hline $\begin{array}{l}u_{1}^{*} \\
\text { 光 } \\
\text { On }\end{array}$ & 으 & ర & $\stackrel{?}{\varrho}$ & ఠิ & లి & $\vec{m}$ & $\underset{N}{ }$ & 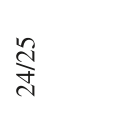 & $n$ & $\stackrel{\mathcal{F}}{\mathcal{T}}$ \\
\hline 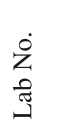 & 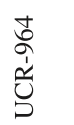 & 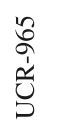 & 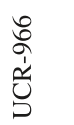 & 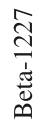 & $\begin{array}{l}\text { o̊ } \\
\text { } \\
\text { I }\end{array}$ & 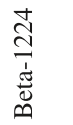 & $\begin{array}{l}8 \\
8 \\
0 \\
1\end{array}$ & $\begin{array}{l}\text { बे } \\
\text { I }\end{array}$ & 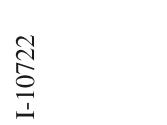 & 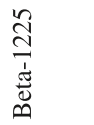 \\
\hline
\end{tabular}




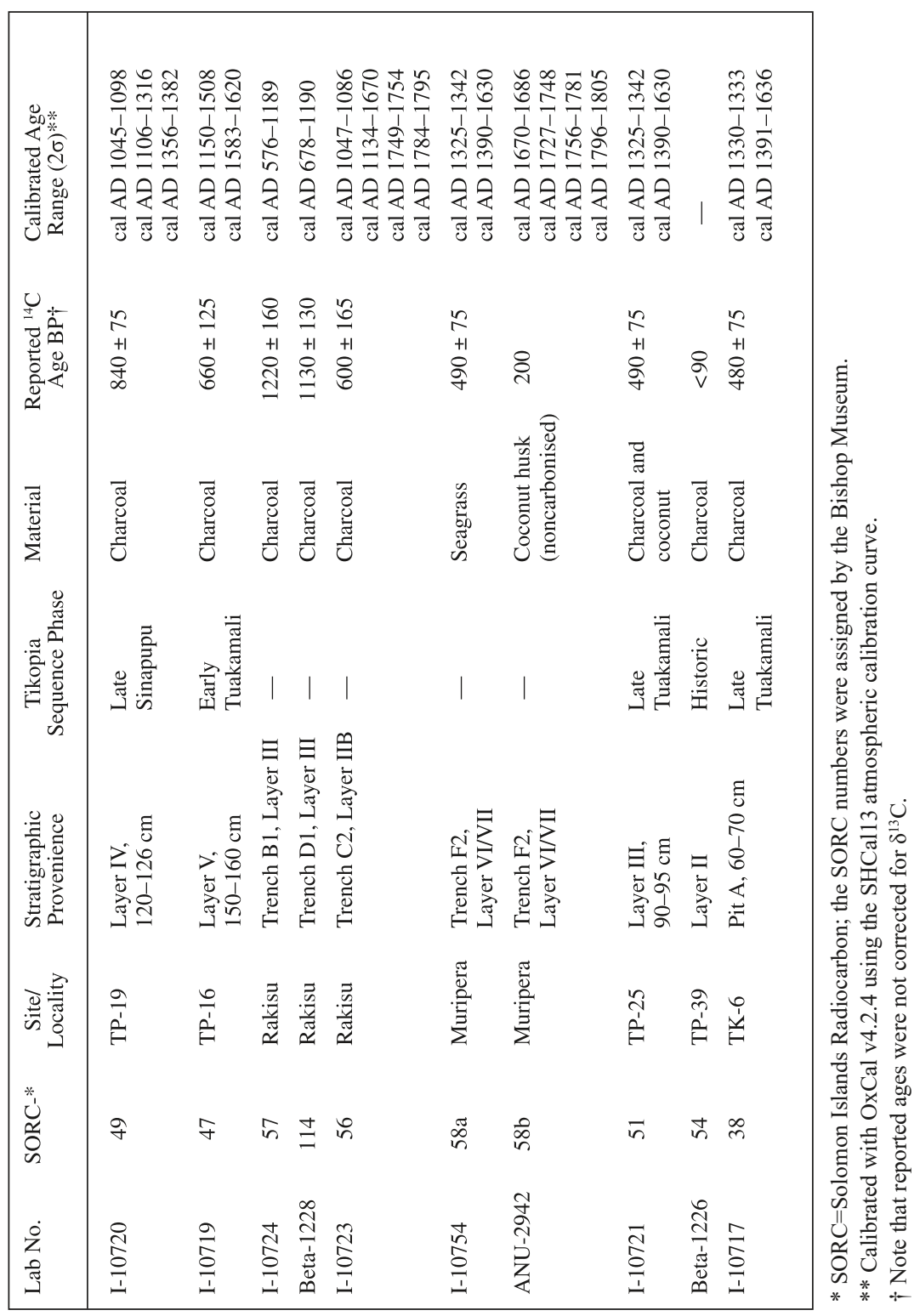




\section{AMS RADIOCARBON DATING RESULTS}

Twenty-four samples were submitted to the University of California, Irvine W.M. Keck Carbon Cycle AMS facility for dating: eleven consisting of Pacific rat bones, six of pig teeth and seven of carbonised coconut endocarp. Unfortunately, only four rat bone and two pig tooth samples yielded sufficient collagen for AMS dating. All of the submitted carbonised coconut endocarp samples were dated. The results of AMS dating on these 13 samples are presented in Table 2. Age ranges shown in Table 2 were calibrated using OxCal v4.2.4 with the SHCal13 atmospheric calibration curve (Bronk Ramsey 2009b; Hogg et al. 2013), and are given at $2 \sigma$ ranges ( $95.4 \%$ confidence intervals).

Carbon stable isotope ratios of pig and rat samples were evaluated for potential marine dietary contributions, as intake of marine reservoir ${ }^{14} \mathrm{C}$ can influence calendar age radiocarbon results by several hundred years. Assuming an entirely terrestrial $\mathrm{C}_{3}$ diet would produce bone collagen $\delta^{13} \mathrm{C}$ values of around $-20 \pm 1 \%$ (Clark et al. 2013), the $\delta^{13} \mathrm{C}$ value of only one sample in this study (SORC-133, $\delta^{13} \mathrm{C}=-17.0$ ) suggests a marine dietary contribution (though this value may also be produced by consumption of $\mathrm{C}_{4}$ plants such as sugarcane and other tropical grasses). The proportion of potential marine dietary carbon in the SORC-133 sample may offset the date produced by up to around 100 years (Petchey et al. 2014); however, this would not substantially alter the model produced here.

The cultural associations of the 13 new AMS dates are provided in Table 3. Two samples (UCIAMS-163474 and -163477) are from Kiki Phase contexts from sites TK-4 and TK-36 respectively. Site TK-4 is regarded as the oldest cultural deposit on Tikopia, containing a number of exotic (i.e., non-local) artefacts (metavolcanic adzes, obsidian from an Admiralty Islands source, chert from a probable Solomon Islands source). Kirch and Yen (1982: 111$25,312-14)$ regarded TK-4 as the most likely locus of the island's founding settlement. TK-36 is part of the long Sinapupu transect (Kirch and Yen 1982, Fig. 30); the deeper layers there contain calcareous-tempered ceramics very similar to those from site TK-4. As indicated in Table 2, the two new dates from these sites yielded nearly identical ages. While these dates are consistent with two dates obtained previously for these sites (UCR-964 and -966; see Table 1), their much tighter error ranges provide greater precision in estimating the date of initial human colonisation of Tikopia.

Three of the new dates (UCIAMS-163457, -163475 and -163476) are assigned to the Early Sinapupu Phase. UCIAMS-163457 came from a deep stratigraphic context in site TK-1 where it was associated with incised pottery of exotic origin (likely from Vanuatu) and Trochus shell armbands. The date provides a good estimate for the later part of the Early Sinapupu Phase. 


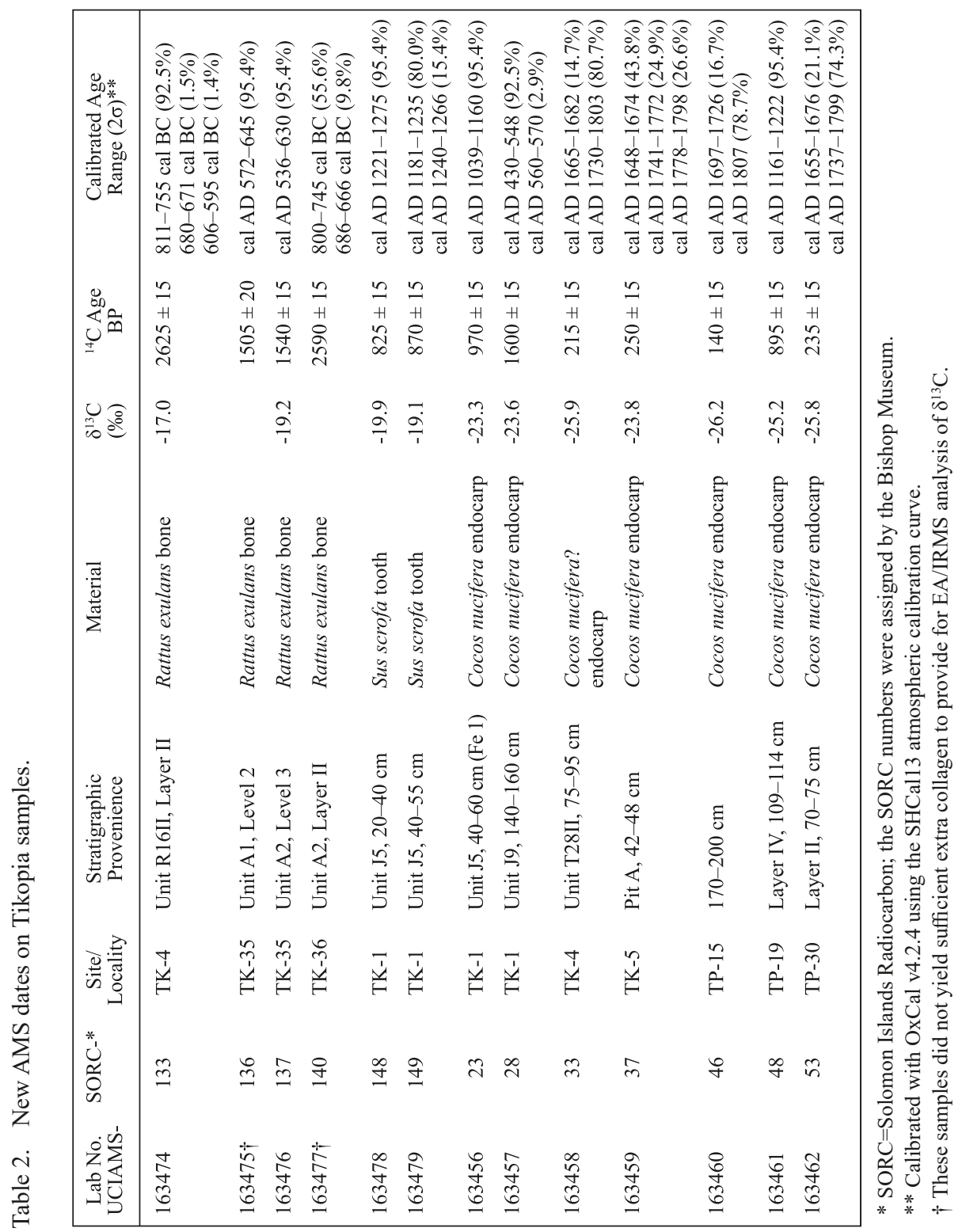


Samples UCIAMS-163475 and -163476 both came from site TK-35, part of the deep Sinapupu sequence, where they were associated with Tridacnashell adzes, Trochus shell armrings and a drilled shell ornament. One of the new dates (UCIAMS-163461) came from a Late Sinapupu Phase context, TP-19, associated with exotic Sinapupu Ware ceramics and a Tridacna shell adze. The age of this sample provides a good estimate for the beginning of the Late Sinapupu Phase.

Three of the new dates (UCIAMS-163478, -163479 and -163456) derive from Early Tuakamali Phase contexts, all from excavation unit J5 in site TK-1. In these stratigraphic contexts, ceramics are entirely lacking and associated cultural artefacts include Tridacna shell adzes and obsidian of the Banks Islands (northern Vanuatu) source. The oldest (UCIAMS-163456) and the youngest (UCIAMS-163478) of these dates bracket the Early Tuakamali Phase.

The remaining four dates (UCIAMS-163458, -163459, -163460 and -163462) all can be assigned to Late Tuakamali or early Historic (i.e., postEuropean contact) phases. One sample (UCIAMS-163459) is associated with a traditional religious site (marae), while two samples (UCIAMS-163460 and -163462) come from occupation deposits directly underlying the modern village hamlets of Paepaevaru and Potu sa Kafika (Kirch and Yen 1982: 13841, 160-62). All four samples yielded ages of less than 250 years BP, with calibrated age ranges in the 17 th and 18 th centuries. The relatively recent date from Potu sa Kafika is of particular interest, as this hamlet is situated on the low-lying sandy tombolo that forms a barrier between the crater lake (Te Roto) and the sea. The Potu sa Kafika date provides a terminus ante quem for the formation of the tombolo, which formed no later than the 18th century AD. As discussed in detail by Kirch and Yen (1982: 346-49), the formation of the tombolo was a key event in Tikopia history, because the resulting transformation of a marine embayment into a brackish-water lake had major consequences for the communities residing around the lake's perimeter.

The Sinapupu area on the island's northwestern side, which includes sites TK-1, TK-35, TK-36 and transect units TP-20 and TP-46 to -53 (inclusive), provided the key to the island's cultural sequence due to its deep and continuous stratigraphy (Kirch and Yen 1982: 89-111, Fig. 30). Seven of the original radiocarbon dates, and eight of the new AMS dates, come from these Sinapupu excavation units. Figure 1 shows these 15 radiocarbon dates, plotted in stratigraphic order. With one exception, the dates correspond to their relative stratigraphic positions. Sample I-10699, which came from site TK-1, is clearly out of stratigraphic order, and represents a "Type T" outlier (Bronk Ramsey 2009b), in which the dated sample does not properly correspond to the event presumed to be dated. This could either be because the unidentified wood charcoal consisted of old wood with an in-built age, 
Patrick V. Kirch \& Jillian A. Swift 321

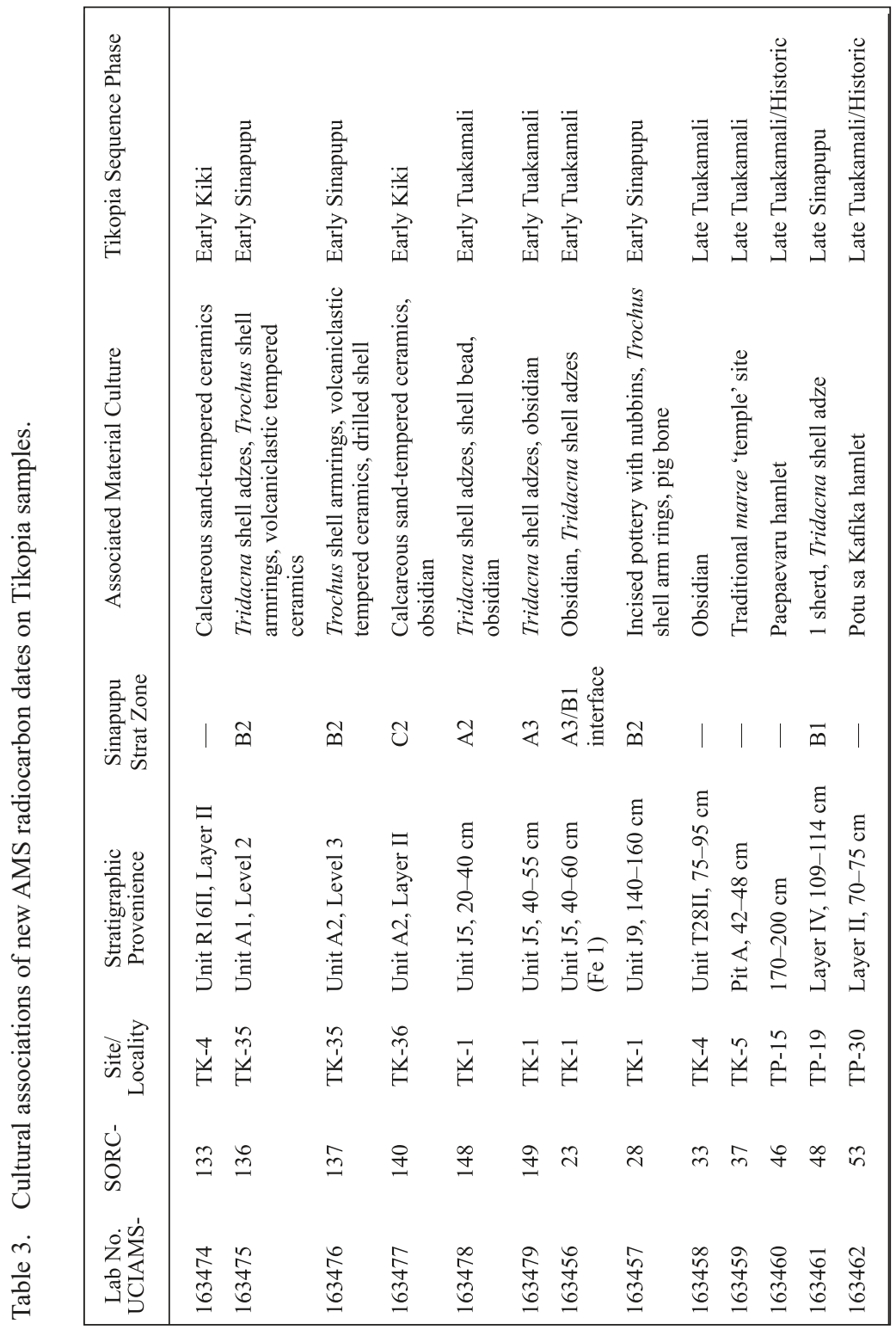




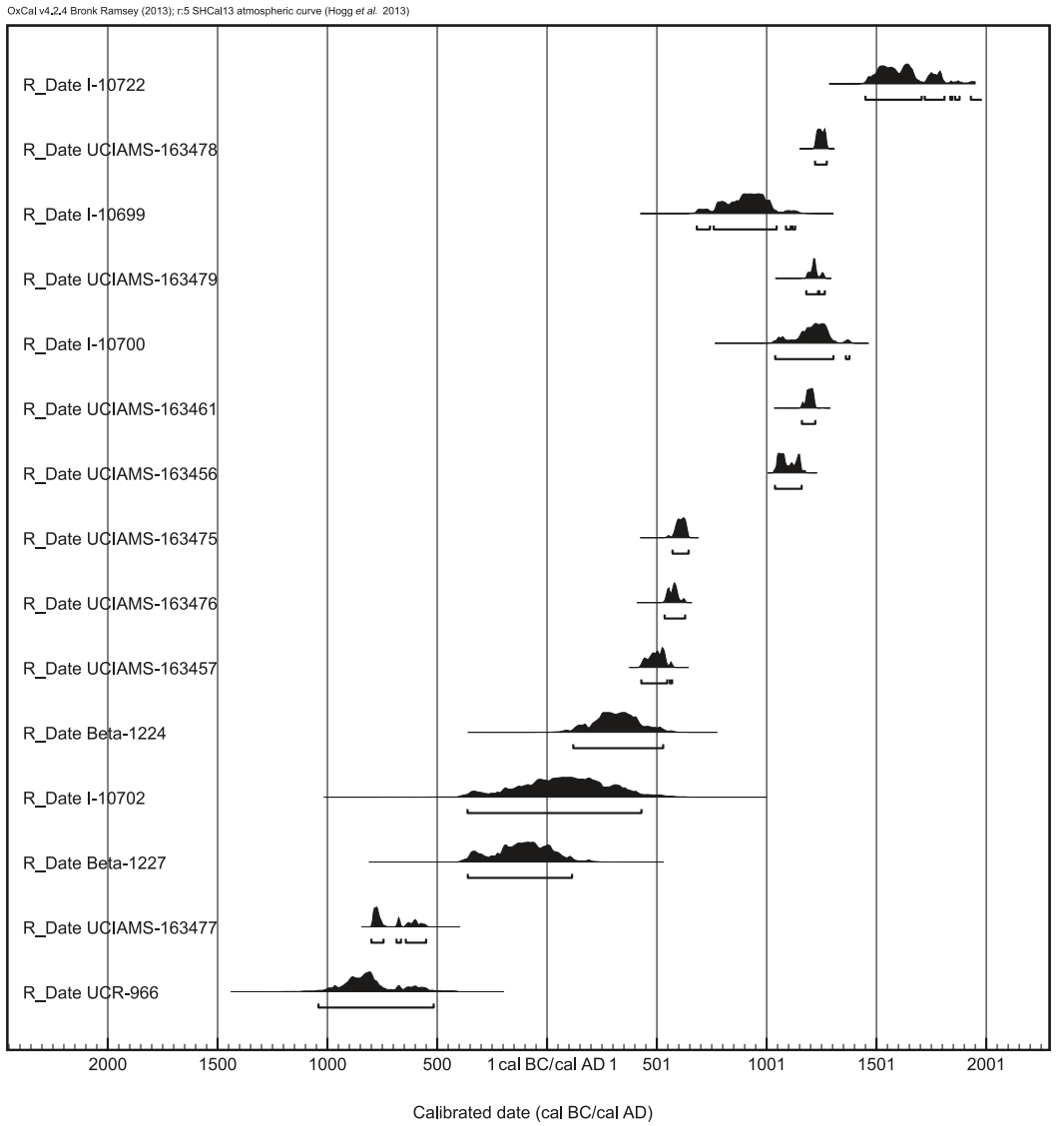

Figure 1. OxCal plot of 15 original and new radiocarbon dates from the Sinapupu area of Tikopia, plotted in stratigraphic order. 
OxCal v4.2.4 Bronk Ramsey (2013); r:5 SHCal13 atmospheric curve (Hogg et al. 2013)

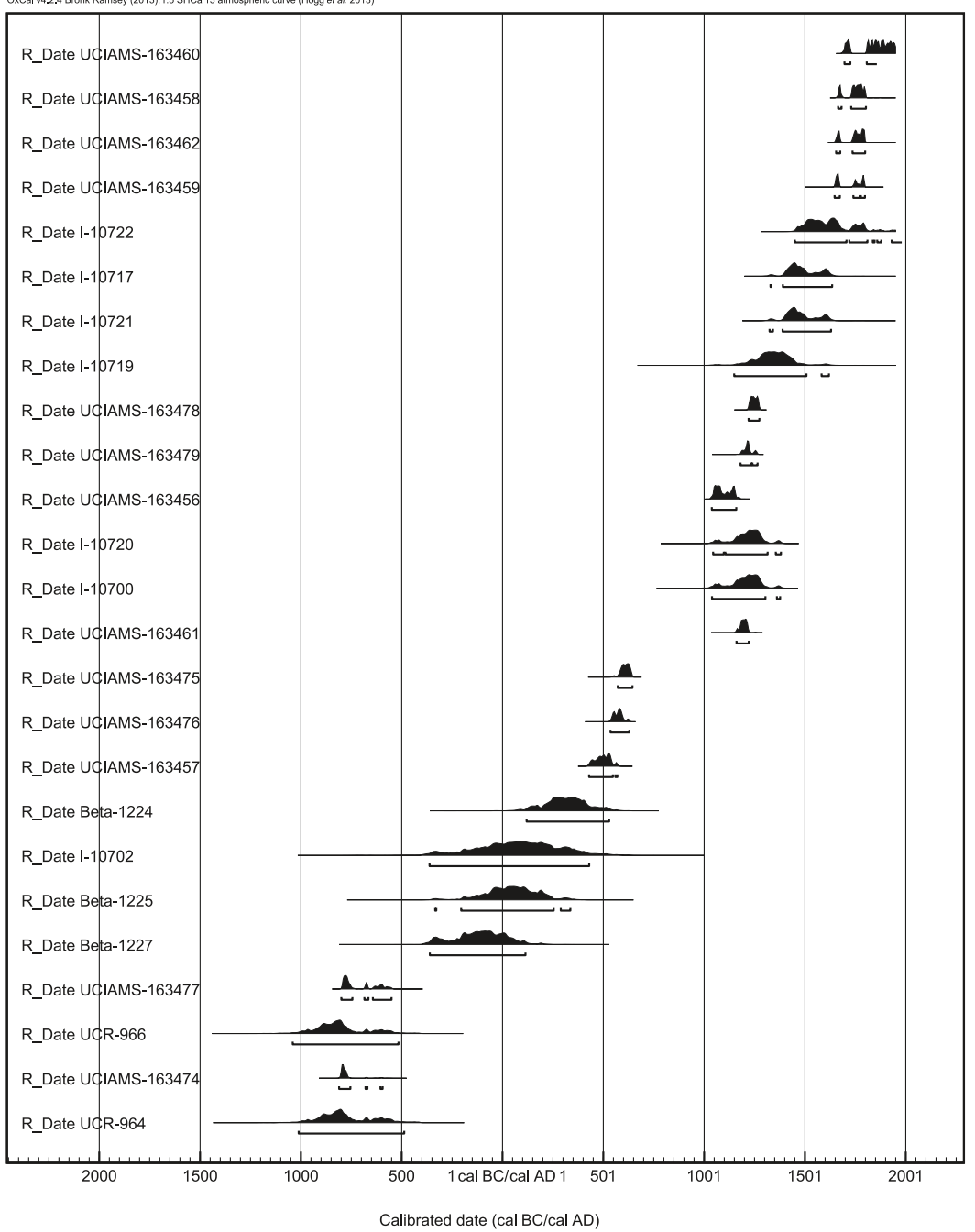

Figure 2. OxCal plot of 25 old and new radiocarbon dates from Tikopia, in inferred stratigraphic order. 
or - more likely - due to the vertical displacement of older charcoal within the TK-1 site due to the digging of deep burial pits within the confines of this structure in the Late Tuakamali Phase.

An additional 11 radiocarbon dates from sites and transect pits outside of the Sinapupu area can be placed along with those from Sinapupu into a relative stratigraphic sequence based on their cultural contents (this excludes the five dates listed in Table 1 from the Rakisu agricultural area and the Muripera swamp, both of which lack associated artefact assemblages, and one very recent date from TP-39). Figure 2 is an integrated plot of these 25 dates (excluding the TK-1 outlier I-10699) from all cultural contexts.

\section{BAYESIAN MODELLING OF THE TIKOPIA SEQUENCE}

The original set of radiocarbon dates from Tikopia (Table 1) was characterised by low precision, with standard errors (68\% probability) ranging from 65 up to 165 years. Given the inherent uncertainty in this suite of dates, and following common practice three to four decades ago, Kirch and Yen (1982) assigned temporal spans to the three culturally defined phases of the Tikopia sequence based on an ad hoc approach, which can be described as "eyeballing". The recent development of Bayesian modelling for the calibration of radiocarbon data sets, which incorporates prior knowledge regarding the stratigraphic relationships among sets of samples, now allows for a more rigorous approach to temporally calibrating cultural sequences such as that for Tikopia. Bayesian modelling has recently been applied with considerable success in Pacific prehistory, as for example in Tonga (Burley et al. 2015), Sāmoa (Clark et al. 2016), Hawai'i (Athens et al. 2014), and Aitutaki (Allen and Morrison 2013) and Mangaia (Kirch 2017) in the Cook Islands.

We applied Bayesian modelling to the integrated suite of 25 radiocarbon dates shown in Figure 2. In addition to excluding sample I-10699 for reasons discussed above, we also excluded an anomalously early date from a pre-Kiki Phase deposit in TP-52 at Sinapupu (UCR-965; see Table 1). This sample predates any known cultural deposits elsewhere in this part of Remote Oceania (Sheppard et al. 2015), and must also be regarded as a Type T outlier, probably due to in-built age. Our Bayesian model also did not incorporate the samples from the Rakisu agricultural zone (I-10724, Beta-1228 and I-10723) or the Muripera swamp area (I-10754 and ANU-2942) as these do not have artefact assemblages permitting them to be assigned to the Tikopia cultural phases. The Bayesian calibration was thus based on 25 radiocarbon dates: four from the Early Kiki Phase, one from the Late Kiki Phase, six from the Early Sinapupu Phase, three from the Late Sinapupu Phase, three from the Early Tuakamali Phase and eight from the Late Tuakamali to Historic Phases. 
We used the $\mathrm{BCal}$ online calibration tool hosted by the University of Sheffield (http://bcal.shef.ac.uk/; see Buck et al. 1999) to construct our Bayesian model. Six groups were specified in the model, each corresponding to one of the phases just mentioned. Based on prior stratigraphic information, the boundary parameters between the phases were specified as sequential and non-overlapping (i.e., Late Kiki Phase earlier than Early Sinapupu Phase, and so on). No floating parameters were specified. For each group, the BCal program calculated $\alpha$ and $\beta$ statistical parameters (highest posterior density estimates, HPD) defining the beginning and ending probabilities for the group. For those unfamiliar with Bayesian terminology, given a group or phase, $k$, within a stratigraphic or chronological sequence, with one or more radiocarbon dates, the time period represented by phase $k$ can be stated as $\alpha_{k}$ minus $\beta_{k}$, where $\alpha$ (the alpha parameter) is the early bounding temporal estimate for group $k$ and $\beta$ (the beta parameter) is the later bounding temporal estimate. Individual likelihood estimates are provided by the radiocarbon dates (the theta parameters) associated with group $k$, designated $\theta k_{(1),}, \theta k_{(2)} \ldots$ $\theta k_{(\mathrm{n})}$. The relationship between all three parameters can be stated as: $\alpha_{k}>\theta_{k(1 \ldots \mathrm{n})}$ $>\beta_{k}$. If group $k$ overlies or supersedes another group $j$, then the relationship between those two groups would be specified as:

$$
\alpha_{j}>\theta_{j(1 \ldots \mathrm{n})}>\beta_{j} \geq \alpha_{k}>\theta_{k(1 \ldots \mathrm{n})}>\beta_{k} .
$$

Results of the calibrated Bayesian model for the Tikopia Phase are presented in Table 4, with the HPD estimates (at 95\%) for the $\alpha$ and $\beta$ parameters for each phase. Table 5 presents the calibrated age ranges (HPD ranges for the $\theta$ parameters) for each of the 25 radiocarbon dates used in the Bayesian model. Figures 3, 4 and 5 graphically display the HPD regions (95\% probability) for the $\alpha$ and $\beta$ parameters for the Kiki, Sinapupu and Tuakamali Phases of the Tikopia sequence. Finally, Table 6 presents estimated elapsed time ranges for each of the modelled groups.

\section{DISCUSSION}

Kirch and Yen (1982) "eyeballed" the settlement of Tikopia at 900 BC based on the original set of radiocarbon dates. A Bayesian model now more precisely brackets initial human colonisation of Tikopia to sometime between 1046-1031, 1029-769 cal BC ( $\alpha 1$ parameter, Table 4). The new AMS dates from the earliest cultural deposits at sites TK-4 and TK-36 (UCIAMS-163474 and -163477; see Table 2) have HPD regions of 805-767 cal BC $(\theta 2)$ and $801-746,680-669$ cal BC $(\theta 4)$, allowing us to more precisely define the time frame for initial occupation at these localities. Based on radiocarbon dating and a Bayesian calibration for the SE-SZ-8 Lapita site of Nanggu, Santa Cruz Islands (Nendö), Green et al. (2008) put the initial Lapita incursion into 
Table 4. Highest posterior density (HPD) estimates for Tikopia phases.

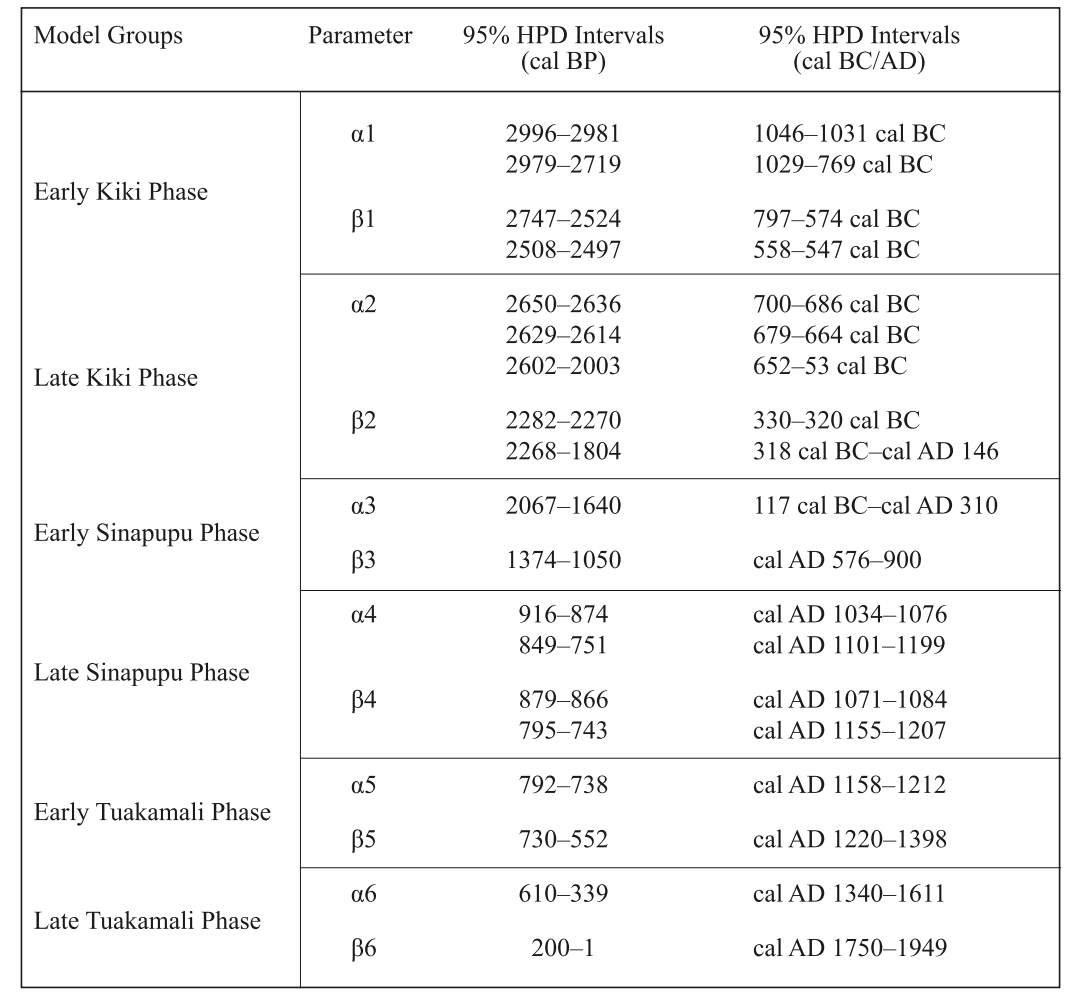

the Reef-Santa Cruz Islands at approximately $1250 \mathrm{cal}$ BC. More recently, based on a re-excavation at the Nanggu site and Bayesian calibration of all radiocarbon dates from Nanggu and the Nenumbo (RF-2) site in the Reef Islands, Sheppard et al. (2015) conclude that Lapita movement into the Santa Cruz Islands did not commence before about $1050 \mathrm{cal} \mathrm{BC}$. This suggests that the colonisation of Tikopia took place 200 to 250 years following the first entry of humans in this part of Remote Oceania.

It is also instructive to compare the estimated date of colonisation of Tikopia with the settlement chronologies of two other Polynesian Outliers in the region, Anuta and Taumako. Anuta, a very small island $\left(\right.$ area $\left.0.4 \mathrm{~km}^{2}\right)$ situated $137 \mathrm{~km}$ northeast of Tikopia, was archaeologically investigated by Kirch and 
Table 5. Bayesian posterior age estimates for individual radiocarbon dates from Tikopia.

\begin{tabular}{|c|c|c|c|c|}
\hline $\begin{array}{c}\text { BCal } \\
\text { Model } \\
\text { Parameter }\end{array}$ & Lab No. & Phase & $\begin{array}{l}95 \% \text { HPD } \\
\text { Intervals } \\
\text { (cal BP) }\end{array}$ & $\begin{array}{l}\text { 95\% HPD Intervals } \\
\text { (cal BC/AD) }\end{array}$ \\
\hline$\theta 1$ & UCR-964 & Early Kiki & $\begin{array}{l}2856-2676 \\
2630-2614\end{array}$ & $\begin{array}{l}906-726 \mathrm{cal} \mathrm{BC} \\
680-664 \mathrm{cal} \mathrm{BC}\end{array}$ \\
\hline$\theta 2$ & UCIAMS-163474 & Early Kiki & $2755-2717$ & $805-767 \mathrm{cal} \mathrm{BC}$ \\
\hline$\theta 3$ & UCR-966 & Early Kiki & $2867-2683$ & $917-733 \mathrm{cal} \mathrm{BC}$ \\
\hline$\theta 4$ & UCIAMS-163477 & Early Kiki & $\begin{array}{l}2751-2696 \\
2630-2619\end{array}$ & $\begin{array}{l}801-746 \mathrm{cal} \mathrm{BC} \\
680-669 \mathrm{cal} \mathrm{BC}\end{array}$ \\
\hline$\theta 5$ & Beta-1227 & Late Kiki & $2313-1923$ & $363 \mathrm{cal} \mathrm{BC}-\mathrm{cal} \mathrm{AD} 27$ \\
\hline$\theta 6$ & Beta-1225 & Early Sinapupu & $1941-1576$ & cal AD 9-374 \\
\hline$\theta 7$ & $\mathrm{I}-10702$ & Early Sinapupu & $\begin{array}{l}1927-1467 \\
1465-1453 \\
1449-1439 \\
1437-1418\end{array}$ & $\begin{array}{l}\mathrm{cal} \text { AD } 23-483 \\
\mathrm{cal} \text { AD } 485-497 \\
\mathrm{cal} \text { AD } 501-511 \\
\mathrm{cal} \text { AD 513-532 }\end{array}$ \\
\hline$\theta 8$ & Beta-1224 & Early Sinapupu & $\begin{array}{l}1795-1764 \\
1752-1448 \\
1446-1423\end{array}$ & $\begin{array}{l}\mathrm{cal} \text { AD } 155-186 \\
\mathrm{cal} \text { AD } 198-502 \\
\mathrm{cal} \text { AD } 504-527\end{array}$ \\
\hline$\theta 9$ & UCIAMS-163457 & Early Sinapupu & $1519-1403$ & $\mathrm{cal} \mathrm{AD} 431-547$ \\
\hline$\theta 10$ & UCIAMS-163476 & Early Sinapupu & $1413-1346$ & cal AD 537-604 \\
\hline$\theta 11$ & UCIAMS-163475 & Early Sinapupu & $1378-1308$ & $\mathrm{cal}$ AD 572-642 \\
\hline$\theta 12$ & UCIAMS-163461 & Late Sinapupu & $796-751$ & cal AD 1154-1199 \\
\hline$\theta 13$ & $\mathrm{I}-10700$ & Late Sinapupu & $\begin{array}{l}899-871 \\
816-748\end{array}$ & $\begin{array}{l}\mathrm{cal} \text { AD } 1051-1079 \\
\mathrm{cal} \text { AD } 1134-1202\end{array}$ \\
\hline$\theta 14$ & I-10720 & Late Sinapupu & $\begin{array}{l}900-870 \\
815-748\end{array}$ & $\begin{array}{l}\text { cal AD } 1050-1080 \\
\text { cal AD } 1135-1202\end{array}$ \\
\hline$\theta 15$ & UCIAMS-163456 & Early Tuakamali & $784-736$ & cal AD 1166-1214 \\
\hline$\theta 16$ & UCIAMS-163479 & Early Tuakamali & $\begin{array}{l}764-716 \\
704-687\end{array}$ & $\begin{array}{l}\text { cal AD } 1186-1234 \\
\text { cal AD } 1246-1263\end{array}$ \\
\hline$\theta 17$ & I-10719 & Early Tuakamali & $772-612$ & cal AD $1178-1338$ \\
\hline
\end{tabular}




\begin{tabular}{|c|c|c|c|c|}
\hline $\begin{array}{c}\text { BCal } \\
\text { Model } \\
\text { Parameter }\end{array}$ & Lab No. & Phase & $\begin{array}{l}95 \% \text { HPD } \\
\text { Intervals } \\
\text { (cal BP) }\end{array}$ & $\begin{array}{l}\text { 95\% HPD Intervals } \\
\text { (cal BC/AD) }\end{array}$ \\
\hline$\theta 18$ & UCIAMS-163478 & Early Tuakamali & $730-680$ & cal AD $1220-1270$ \\
\hline$\theta 19$ & I-10721 & Late Tuakamali & $\begin{array}{l}532-433 \\
418-307\end{array}$ & $\begin{array}{l}\text { cal AD 1418-1517 } \\
\text { cal AD 1532-1643 }\end{array}$ \\
\hline$\theta 20$ & I-10717 & Late Tuakamali & $\begin{array}{l}526-424 \\
422-309\end{array}$ & $\begin{array}{l}\text { cal AD } 1424-1526 \\
\text { cal AD } 1528-1641\end{array}$ \\
\hline$\theta 21$ & I-10722 & Late Tuakamali & $\begin{array}{l}470-254 \\
221-147\end{array}$ & $\begin{array}{l}\text { cal AD 1480-1696 } \\
\text { cal AD 1729-1803 }\end{array}$ \\
\hline$\theta 22$ & UCIAMS-163459 & Late Tuakamali & $\begin{array}{l}302-277 \\
310-180 \\
171-154\end{array}$ & $\begin{array}{l}\text { cal AD } 1648-1673 \\
\text { cal AD 1640-1770 } \\
\text { cal AD } 1779-1796\end{array}$ \\
\hline$\theta 23$ & UCIAMS-163462 & Late Tuakamali & $\begin{array}{l}295-275 \\
214-153\end{array}$ & $\begin{array}{l}\text { cal AD 1655-1675 } \\
\text { cal AD 1736-1797 }\end{array}$ \\
\hline$\theta 24$ & UCIAMS-163458 & Late Tuakamali & $\begin{array}{l}286-267 \\
220-149\end{array}$ & $\begin{array}{l}\text { cal AD } 1664-1683 \\
\text { cal AD } 1730-1801\end{array}$ \\
\hline$\theta 25$ & UCIAMS-163460 & Late Tuakamali & $\begin{array}{l}266-221 \\
146-81 \\
72-60\end{array}$ & $\begin{array}{l}\mathrm{cal} \text { AD } 1684-1729 \\
\mathrm{cal} \text { AD } 1804-1869\end{array}$ \\
\hline
\end{tabular}

Table 6. Modelled elapsed time estimates for Tikopia cultural phases.

\begin{tabular}{|ll|}
\hline Phase & Elapsed Time (years) \\
\hline Early Kiki & $0-401,403-417$ \\
Late Kiki & $0-525,527-560,562-609$ \\
Early Sinapupu & $323-893,895-934$ \\
Late Sinapupu & $0-106$ \\
Early Tuakamali & $17-234$ \\
Late Tuakamali & $165-562$ \\
\hline
\end{tabular}



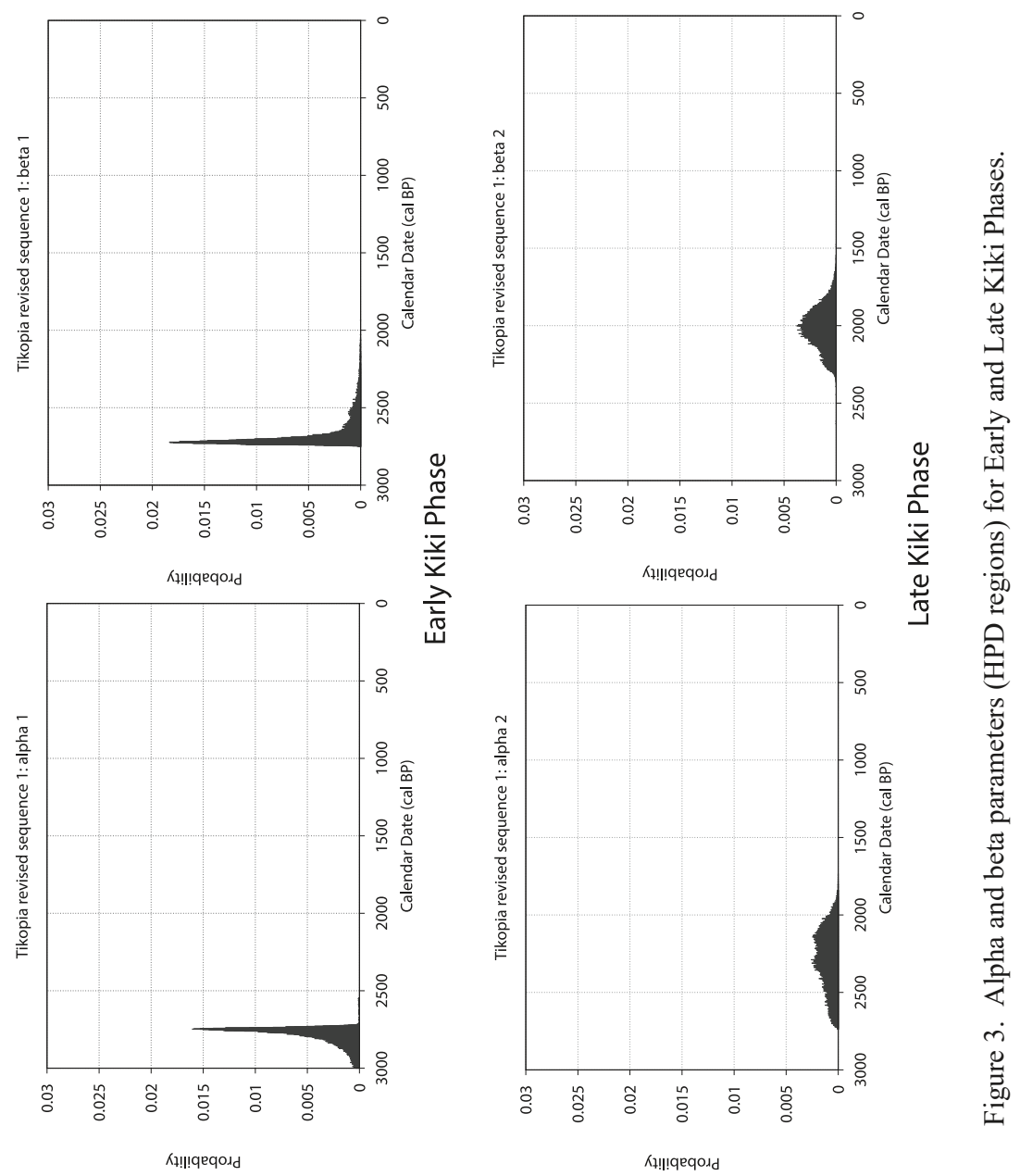


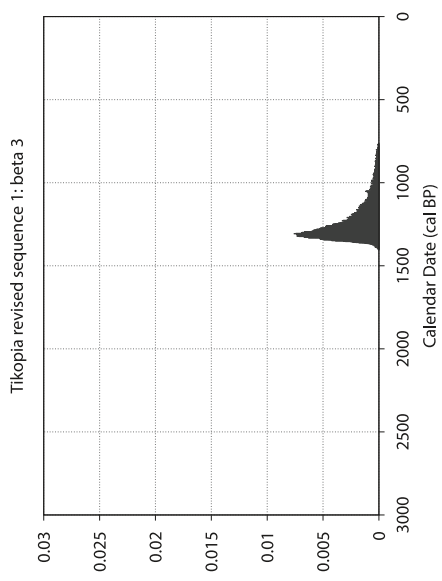

K!!!!qeqodd

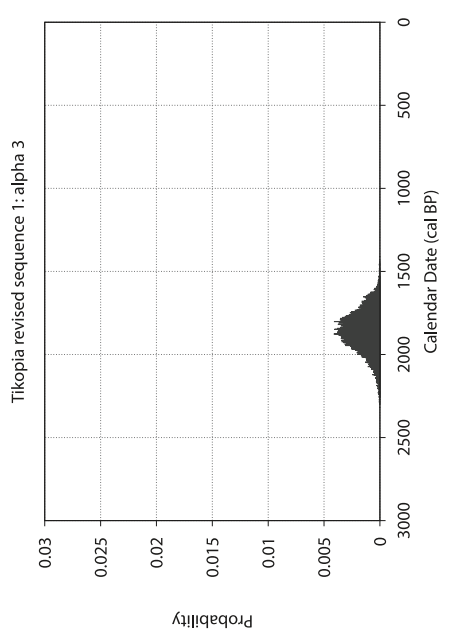

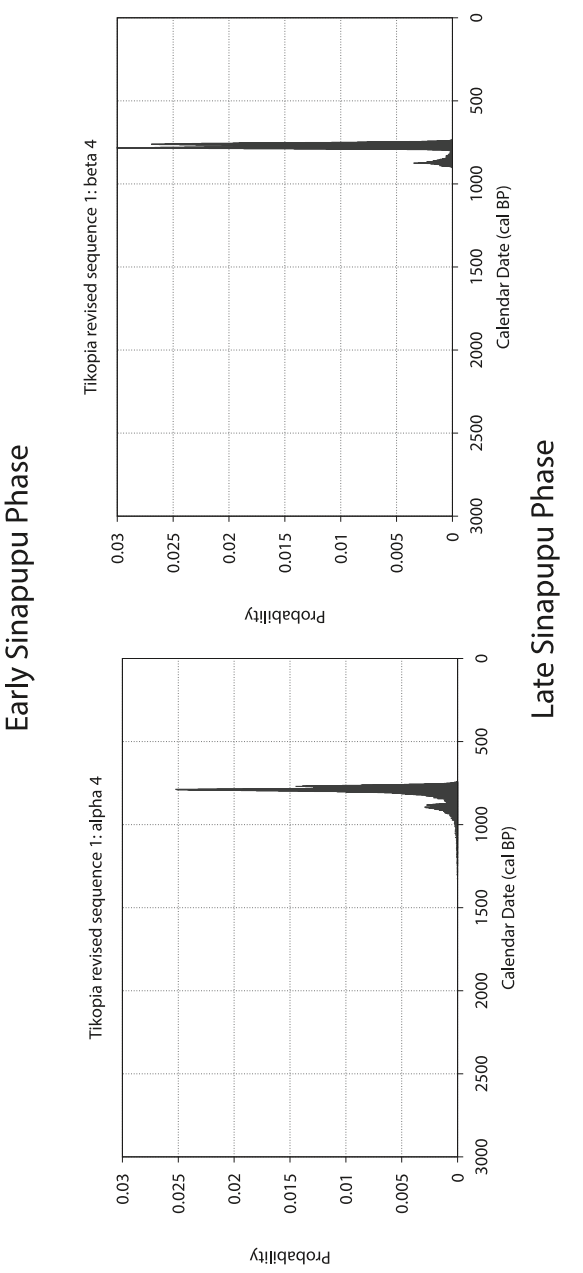



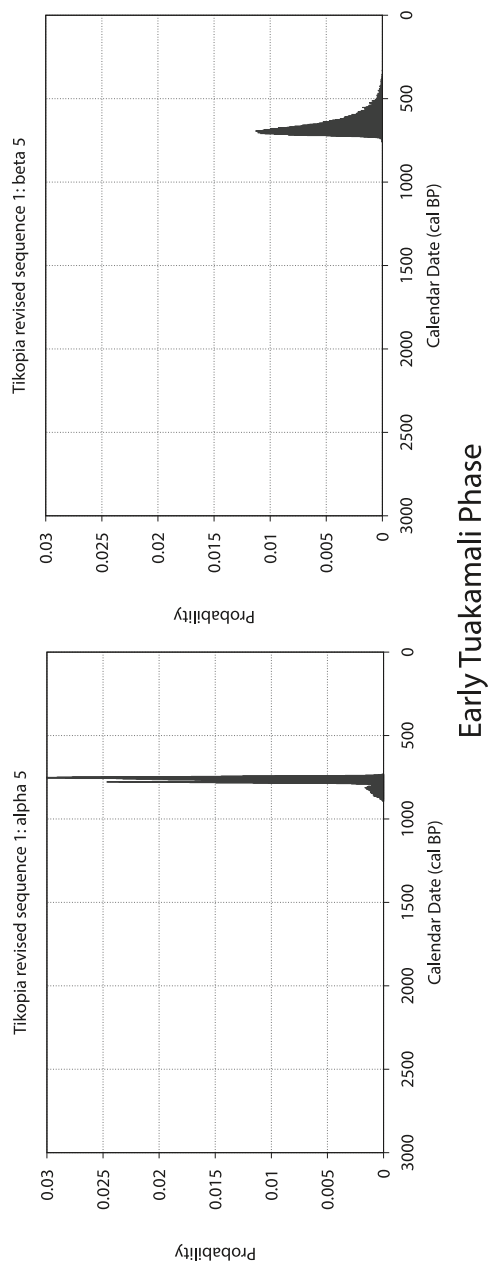
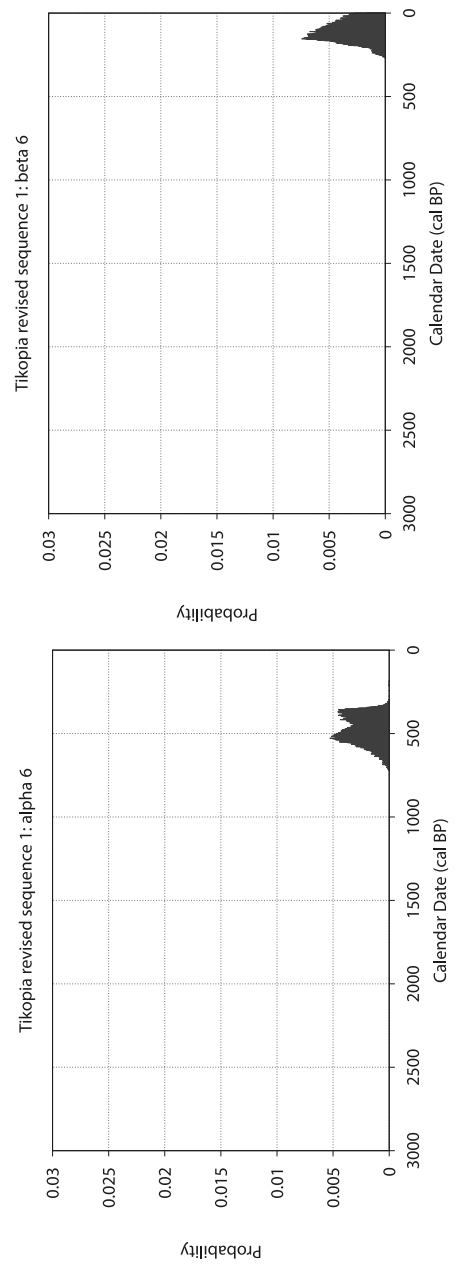

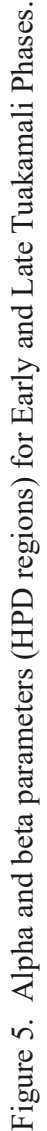


Rosendahl (1973). Layer III at the AN-6 site, which contained calcareoustempered ceramics nearly identical to the Kiki Ware of Tikopia, was dated with three charcoal samples (I-6274, -6272 and -6275, Kirch and Rosendahl 1973, Table 31 ). The samples yielded calibrated age ranges (95.4\% probability) of 843-406, 896-427 and 1297-833 cal BC. The last of these seems improbably old and may reflect an "old wood" issue, but the first two are consistent with the estimated age of the Kiki Phase on Tikopia. For Taumako, the earliest occupation deposits in the Ana Tavatava site likewise yielded a ceramic assemblage not unlike that from the TK-4 site, with an associated radiocarbon date (NZ-4641) of $2602 \pm 64 \mathrm{BP}$, with a calibrated range of 834-475 cal BC (Leach and Davidson 2008: 295-96, Table A12.1). This is again consistent with the Early Kiki Phase dating. In sum, all three of these islands-Tikopia, Anuta and Taumako - appear to have been first settled at approximately the same time by populations all producing similar, largely plainware ceramics.

The transition from the Kiki Phase to the Early Sinapupu Phase is the most difficult to pin down in absolute chronological terms. There is just one radiocarbon date (Beta-1227) from a Late Kiki Phase context, TP-48 of the Sinapupu site transect (see Table 1). Bayesian calibration yields a 95\% HPD estimate for this date $(\theta 5)$ of $363 \mathrm{cal} \mathrm{BC}$ to cal AD 27 . Parameter $\beta 2$, for the end of the Kiki Phase, has HPD intervals of 330-320 cal BC and $318 \mathrm{cal}$ $\mathrm{BC}$ to cal AD 146. Parameter $\alpha 3$, for the beginning of the Early Sinapupu Phase, has a 95\% HPD region of 117 cal BC to cal AD 310. In sum, the Kiki to Sinapupu transition occurred sometime between the late first millennium $\mathrm{BC}$ and the early first millennium AD. Defining the timing of this transition more precisely would require further datable samples from Late Kiki Phase or Early Sinapupu Phase contexts.

The Sinapupu Phase on Tikopia is characterised by a number of distinct changes in material culture and in the exploitation of particular faunal resources, but the most notable feature is the importation of distinctive incised ceramics from one or more sources in the Vanuatu archipelago (the Sinapupu Ware ceramics, described by Kirch and Yen 1982: 200-202). This incised pottery falls within the overall ceramic tradition known as Mangaasi, originally defined by Garanger $(1971,1972)$. Bedford (2006, Fig. 8.16) has defined the ceramic traditions of various subgroups within the extensive Vanuatu archipelago, noting that Mangaasi-style ceramics occur in both the Shepherd Group and on Efate between approximately $250 \mathrm{cal}$ BC and cal AD 750. This correlates reasonably well with the time frame estimated for the Early and Late Sinapupu Phases, bracketed between $117 \mathrm{cal} \mathrm{BC}$ to cal AD $310(\alpha 3)$ and cal AD 1071-1084, 1155-1207 ( $\beta 4)$ (Table 4).

The transition from the Late Sinapupu to the Early Tuakamali Phase marks another major cultural transition on the island, one that is reflected in 
material culture with distinctively Polynesian traits such as basalt adzes and trolling lures of Western Polynesian forms (Kirch and Yen 1982: 236-37, $244,333)$. This phase is believed to represent the successive arrival of several Polynesian-speaking groups who were the direct ancestors of the various social lineages presently occupying the island (Kirch and Yen 1982: 341-43). The Bayesian model allows us to define the timing of this transition quite precisely. Parameter $\alpha 5$, for the Early Tuakamali Phase, has an HPD region of cal AD 1158-1212. The earliest radiocarbon date from a Tuakamali Phase context is UCIAMS-163456 from site TK-1, which is associated with Banks Islands obsidian and Tridacna shell adzes (Table 3), and has a modelled age range of cal AD 1166-1214 ( $\theta 15$, Table 5).

It may not be coincidental that the arrival of these Polynesian groups in Tikopia occurred around AD 1100-1200, contemporaneous with the dispersal of Polynesians out of the Western Polynesian homeland region into the archipelagos of Eastern Polynesia (i.e., the Society Islands, Marquesas, Cook Islands, Mangareva and others). While the settlement histories of the Polynesian Outliers and of Eastern Polynesia have typically been treated by culture historians as separate phenomena, it seems possible that both were part of a larger diaspora that extended both east and west out of the Western Polynesian core after AD 1000. In this regard, the linguistic analysis of Wilson (2012), which identifies a common origin in the dialects of certain Polynesian Outliers and those of Eastern Polynesia, may be relevant.

$$
* * *
$$

Additional new high-precision AMS dates for the Tikopia cultural sequence, combined with a Bayesian calibration of a total of 25 radiocarbon dates from the island, allows a reassessment of the original temporal framework proposed by Kirch and Yen (1982). In general terms the new AMS dates confirm the sequence as originally proposed, but it is now possible to more precisely estimate the time spans for the phases of the Tikopia sequence. Initial settlement of Tikopia, originally estimated by Kirch and Yen (1982) to have occurred slightly later than $900 \mathrm{BC}$, can now be estimated to have occurred sometime between 1046-1031, 1029-769 cal BC. The transition between the Kiki and Sinapupu Phases remains less precisely dated due to the limited number of radiocarbon dates, but occurred sometime between 117 cal BC and cal AD 310. The final major change in the cultural sequence, from the Sinapupu to Tuakamali Phases, marked by the arrival of new settlers who had a distinctive Western Polynesian material culture and were presumably the direct ancestors of the ethnographically documented Tikopia, occurred sometime during the period cal AD 1158-1212. 


\section{ACKNOWLEDGEMENTS}

The research reported here was funded by a National Science Foundation Doctoral Dissertation Research Improvement Award (BCS-1452364) to Kirch and Swift. We thank Mara Mulrooney and Charmaine Wong of the Bishop Museum for facilitating access to the Tikopia collections originally excavated by Kirch in 1977-78. John Southon at the W.M. Keck Carbon Cycle Facility at the University of California, Irvine, oversaw the AMS dating of the samples. Caitlin Buck kindly responded to queries regarding the Bayesian calibration of the Tikopia dates using the BCal program.

\section{REFERENCES}

Allen, M.S. and A.E. Morrison, 2013. Modelling site formation dynamics: Geoarchaeological, chronometric and statistical approaches to a stratified rockshelter sequence, Polynesia. Journal of Archaeological Science 40: 4560-75.

Athens, J.S., T.M. Rieth and T.S. Dye, 2014. A paleoenvironmental and archaeological model-based assessment for the colonization of Hawai'i. American Antiquity 79: 144-55.

Bedford, S., 2006. Pieces of the Vanuatu Puzzle: Archaeology of the North, South, and Centre. Terra Australis 23. Canberra: Pandanus Books, Australian National University.

Bronk Ramsey, C., 2009a. Bayesian analysis of radiocarbon dates. Radiocarbon 51: 337-60.

2009b. Dealing with outliers and offsets in radiocarbon dating. Radiocarbon 51:1023-45.

Buck, C.E., J.A. Christen and G.N. James, 1999. BCal: An on-line Bayesian radiocarbon calibration tool. Internet Archaeology 7: http://intarch.ac.uk/journal/issue7/buck/.

Burley, D., K. Edinborough, M.I. Weisler and J. Zhao, 2015. Bayesian modeling and chronological precision for Polynesian settlement of Tonga. PLOS-One, DOI:10.1371/journal.pone.0120795

Clark, G., F. Petchey, S. Hawkins, C. Reepmeyer, I. Smith and W.B. Massey, 2013. Distribution and extirpation of pigs in Pacific Islands: A case study from Palau. Archaeology in Oceania 48 (3): 141-53.

Clark, J.T., S. Quintus, M.I. Weisler, E. St Pierre, L. Nothdurft and Y. Feng, 2016. Refining the chronology for West Polynesian colonization: New data from the Samoan archipelago. Journal of Archaeological Science: Reports 6: 266-74.

Damon, P.E., A. Long and E.I. Wallick, 1972. Dendrochronologic calibration of the Carbon-14 time scale. In T.A. Rafter and T. Grant-Taylor (eds), Proceedings of the Eighth International Radiocarbon Dating Conference. Bulletin of the Royal Society of New Zealand 14. Lower Hutt, New Zealand, 18-25 October 1972, pp. 27-43.

Feinberg, R. and R. Scaglion (eds), 2012. Polynesian Outliers: The State of the Art. Ethnology Monographs No. 21. Pittsburgh: Department of Anthropology, University of Pittsburgh.

Firth, R., 1936. We the Tikopia: A Sociological Study of Kinship in Primitive Polynesia. London: Allen and Unwin. 
1939. Primitive Polynesian Economy. London: Routledge \& Sons.

1961. History and Traditions of Tikopia. Memoir 33. Wellington: The Polynesian Society.

Garanger, J., 1971. Incised and applied-relief pottery, its chronology and development in southeastern Melanesia, and extra areal comparisons. In R.C. Green and M. Kelly (eds), Studies in Oceanic Culture History. Volume 2. Pacific Anthropological Records 12. Honolulu: Bishop Museum, pp. 53-66. 1972. Archéologie des Nouvelles-Hébrides. Publications de la Société des Océanistes 30. Paris.

Green, R.C., 1979. Lapita. In J.D. Jennings (ed.), The Prehistory of Polynesia. Cambridge: Harvard University Press, pp. 27-60.

Green, R.C., M. Jones and P. Sheppard, 2008. The reconstructed environment and absolute dating of SE-SZ-8 Lapita site on Nendö, Santa Cruz, Solomon Islands. Archaeology in Oceania 43: 49-61.

Hogg, A.G., Quan H., P.G. Blackwell, M. Niu, C.E. Buck, T.P. Guilderson, T.J. Heaton, J.G. Palmer, P.J. Reimer, R.W. Reimer, C.S.M. Turney and S.R.H. Zimmerman, 2013. SHCal13 Southern Hemisphere calibration, 0-50,000 Years Cal BP. Radiocarbon 55: 1889-903.

Kirch, P.V. 1984. The Polynesian outliers: Continuity, change, and replacement. Journal of Pacific History 19: 224-38.

1986. Exchange systems and inter-island contact in the transformation of an island society: The Tikopia case. In P.V. Kirch (ed.), Island Societies: Archaeological Approaches to Evolution and Transformation. Cambridge: Cambridge University Press, pp. 33-41.

1997. Microcosmic histories: Island perspectives on "global" change. American Anthropologist 99: 30-42.

2017. Radiocarbon dating and Bayesian modeling of the chronology of Tangatatau Rockshelter. In P.V. Kirch (ed.), Tangatatau Rockshelter: The Evolution of an Eastern Polynesian Socio-Ecosystem. Monumenta Archaeologica 40. Los Angeles: Cotsen Institute of Archaeology Press, pp. 75-90.

Kirch, P.V. and P.H. Rosendahl, 1973. Archaeological investigation of Anuta. In D.E. Yen and J. Gordon (eds), Anuta: A Polynesian Outlier in the Solomon Islands. Pacific Anthropological Records 21. Honolulu: Bishop Museum, pp. 25-108.

Kirch, P.V. and D.E. Yen, 1982. Tikopia: The Prehistory and Ecology of a Polynesian Outlier. Bernice P. Bishop Museum Bulletin 238. Honolulu: Bishop Museum Press.

Leach, F. and J. Davidson, 2008. Archaeology on Taumako: A Polynesian Outlier in the Eastern Solomon Islands. New Zealand Journal of Archaeology Special Publication. Dunedin, New Zealand.

Michael, H.N. and E.K.Ralph, 1972. Discussion of radiocarbon dates obtained from precisely dated sequoia and bristlecone pine samples. In T.A. Rafter and T. Grant-Taylor (eds), Proceedings of the Eighth International Radiocarbon Dating Conference. Bulletin of the Royal Society of New Zealand 14. Lower Hutt, New Zealand, 18-25 October 1972, pp. 12-47.

Petchey, F., M. Spriggs, S. Bedford, F. Valentin and H. Buckley, 2014. Radiocarbon dating of burials from the Teouma Lapita cemetery, Efate, Vanuatu. Journal of Archaeological Science 50: 227-42. 
Sheppard, P. J., S. Chiu and R. Walter, 2015. Re-dating Lapita movement in Remote Oceania. Journal of Pacific Archaeology 6 (1): 26-36.

Southon, J.R., G. Santos, K. Druffel-Rodriguez, E. Druffel, S. Trumbore, X.M. Xu, S. Griffin, S. Ali and M. Mazon, 2004. The Keck Carbon Cycle AMS Laboratory, University of California, Irvine: Initial operation and a background surprise. Radiocarbon 46: 41-49.

Spriggs, M.J.T. and A. Anderson, 1993. Late colonization of East Polynesia. Antiquity 67: 200-217.

Stuiver, M. and H.M. Polach, 1977. Discussion: Reporting of ${ }^{14} \mathrm{C}$ data. Radiocarbon 19 (3): 355-63.

Wilson, W., 2012. Whence the East Polynesians? Further linguistic evidence for a Northern Outlier source. Oceanic Linguistics 51: 289-359.

\begin{abstract}
The Polynesian Outlier of Tikopia, situated in the Santa Cruz Islands group (Temotu Province) of the Solomon Islands, has one of the best-defined archaeological sequences in the southwestern Pacific. Archaeological excavations in 1977-78 yielded a rich record of material culture and faunal remains, with a chronological framework provided by 20 radiocarbon dates. These dates, however, were processed on unidentified wood charcoal using the older liquid-scintillation method; the large standard errors associated with these dates rendered this chronology rather imprecise. Here we report 13 new, high-precision AMS radiocarbon dates on carbonised coconut endocarp, rat bone and pig teeth from the original excavations. The new AMS dates confirm the original sequence and, when combined with the original radiocarbon dates in a Bayesian calibration model, allow for a refinement of the cultural chronology for Tikopia. This updated model provides a more precise chronology for key events in Tikopian prehistory including first human colonisation, the arrival of Polynesianspeaking populations to the island and the formation of the sandy tombolo transforming Te Roto into a brackish-water lake.
\end{abstract}

Keywords: Lapita, Rattus exulans, Tikopia, Polynesian Outliers, Bayesian modelling, Solomon Islands, Remote Oceania

\title{
CITATION AND AUTHOR CONTACT DETAILS
}

Kirch, ${ }^{1}$ Patrick V. and Jillian A. Swift, ${ }^{2}$ 2017. New AMS radiocarbon dates and a re-evaluation of the cultural sequence of Tikopia Island, Southeast Solomon Islands. Journal of the Polynesian Society 126 (3): 313-336. DOI: http://dx.doi.org/10.15286/ jps.126.3.313-336

${ }^{1}$ Corresponding author: Department of Anthropology, University of California at Berkeley, 232 Kroeber Hall, Berkeley, CA 94720, USA. Email: kirch@berkeley. edu

2 Department of Archaeology, Max Planck Institute for the Science of Human History, Kahlaische Strasse 10, D-07743 Jena, Germany. Email: swift@shh.mpg.de 